\title{
ATRYBUCJE I WYJAŚNIANIE PRZYCZYNOWE W BADANIACH NAD TURYSTYKĄ (na przykładzie analiz dotyczących inhibitorów aktywności turystycznej Europejczyków w latach 1997-2014)
}

\section{Wstęp}

Problematyka roli atrybucji $\mathrm{w}$ badaniach nad turystyką poruszana jest stosunkowo rzadko ${ }^{1}$. W niniejszym opracowaniu uwaga została skoncentrowana na atrybucjach przyczynowych oraz ich znaczeniu w procesie wyjaśniania zachowań turystycznych ludności (a dokładniej to ujmując - w wyjaśnianiu braku takich zachowań, czyli $w$ analizach dotyczących przyczyn nieuczestniczenia $w$ turystyce). Praca składa się zasadniczo z dwóch części. W pierwszej, która ma charakter teoretyczny, odniesiono się do problemów determinacji i przyczynowości $\mathrm{w}$ nauce oraz scharakteryzowano - ograniczając się do nauk społecznych - istotę atrybucji i wyjaśniania kazualnego. Rozważania na ten temat stanowią swoisty wstęp do analizy badań empirycznych dotyczących atrybucji przyczyn braku uczestnictwa w wyjazdach turystycznych (nazywanych w tej pracy inhibitorami aktywności turystycznej - por. ALEJZIAK 2007, 2013), które zostały przedstawione w drugiej części

${ }^{1}$ Warto zauważyć, że nawet jeśli atrybucje oraz wyjaśnianie przyczynowe $\mathrm{w}$ istocie stanowią przedmiot takich badań (jak np. w przypadku części badań nad aktywnością turystyczną), to sam termin „atrybucja” zazwyczaj w nich nie występuje. 
pracy. Zaprezentowano tam wyniki kilku badań prowadzonych przez różne instytucje polskie i europejskie, a także rezultaty badań własnych zrealizowanych w ramach projektu „Funkcjonalna typologia uwarunkowań aktywności turystycznej".

\section{Przyczynowość i determinacja a wyjaśnianie w naukach społecznych}

Podstawowym celem nauki jest dostarczanie możliwej do zweryfikowania wiedzy, która pomaga wyjaśnić, przewidzieć i zrozumieć zjawiska empiryczne lub zachowania - w zależności od dyscypliny nauki - rzeczy, zjawisk, ludzi itd. Wyjaśnianie, wokół którego koncentrują się najważniejsze rozważania tej pracy, jest tą funkcją nauki, którą uznaje się za nadrzędną. Przypisywanie mu pierwszeństwa wśród innych celów działalności naukowej wynika z pojmowania eksplanacji jako procesu mającego na celu udzielenie odpowiedzi na pytanie: „dlaczego?”2. Warto jednak podkreślić, że o wyjaśnianiu możemy mówić również w przypadku innych pytań, takich jak: „w jakim celu?", ,kto?”, ,jak?", ,,co?", ,gdzie?”, ,skąd?".

Problematykę wyjaśniania naukowego można rozpatrywać zasadniczo w dwóch pespektywach. Według pierwszej - wyjaśnić dany fakt, to tyle, co wskazać regularność ogólną, której ów jednostkowy fakt jest przypadkiem szczególnym. W tym ujęciu, o fakcie jednostkowym mówimy, że jest wyjaśniony wtedy, gdy wskazane zostaną jego przyczyny, a więc przez stwierdzenie, jakie jest prawo (lub prawa), których pewnym przypadkiem jest realizacja tego faktu. Natomiast według drugiej perspektywy - wyjaśnienie polega na wskazaniu prawa ujawniającego istotę faktu, a wiec zrozumienie go oraz opisanie jego istoty w formie pojęcia (Filozofia a nauka ... 1987, s. 741).

Klasyczny model wyjaśniania naukowego (tzw. schemat dedukcyjno-nomologiczny) został zaproponowany przez C.G. HEMPLA i P. OPPENHEIMA (1948). W modelu tym³ zjawisko, które ma być wyjaśnione nazywane jest zjawiskiem-eksplanandum (od łac. explanandum - „to, co należy wyjaśnić”), zaś zdanie, które je opisuje zdaniem-eksplanandum. Każdy eksplanans składa

2 Pogląd ten prawdopodobnie wywodzi się genetycznie od arystotelesowskiego podziału wiedzy na demonstratywną, czyli odpowiadającą na pytanie "jak?" i teoretyczną - odpowiadającą na pytanie „dlaczego?" (NIKITIN 1975, s. 10-13).

${ }^{3}$ Warto dodać, że model D-N (dedukcyjno-nomologiczny) został później rozszerzony o schemat wyjaśniania dedukcyjno-hipotetycznego (D-H) (HEMPEL 1968, NAGEL 1985). 
się z dwóch metodologicznie różnych części: zdań reprezentujących fakty jednostkowe oraz zdań reprezentujących ogólne prawidłowości. Istotą tego modelu wyjaśniania jest rozumowanie dedukcyjne, którego konkluzją jest zdanie-eksplanandum, a układem przesłanek - eksplanans, składający się z praw ogólnych i ze zdań, które stwierdzają pewne fakty szczegółowe. Za pomocą tego modelu możemy wyjaśniać zarówno fakty jednostkowe (np. dlaczego $X$ wyjechał $w$ danym roku na wakacje a $Y$ nie, lub też np. dlaczego ten pierwszy częściej uprawia turystykę niż ten drugi), jak też ogólne prawidłowości (np. dlaczego ludzie mieszkający w miastach są bardziej aktywni turystycznie od tych, którzy mieszkają na wsi).

W związku z tym, że prawa nauki mogą odzwierciedlać różne stosunki i zależności badanych obiektów (np.: substancjalne, atrybutowe, przyczynowo-skutkowe, funkcjonalne, strukturalne), to różne mogą być też rodzaje wyjaśniania ${ }^{4}$. Zróżnicowanie to, a także podstawowe zastosowania wyjaśniania naukowego przedstawia tab. 1.

Chociaż poszczególne typy wyjaśniania mogą się wzajemnie przenikać i łączyć, to w praktyce najczęściej wyodrębnia się cztery podstawowe rodzaje wyjaśniania: genetyczne, teleologiczne (celowościowe), funkcjonalne i logiczne. Warto też dodać, że nie każdy rodzaj wyjaśniania jest naukowy, a przywołani wcześniej C.G. Hempel i P. Oppenheim podali nawet warunki, które muszą być spełnione, aby wyjaśnianie miało charakter naukowy: eksplanandum musi być konsekwencją logiczną eksplanansu, zdania tworzące eksplanans muszą być prawdziwe, zaś sam eksplanans musi zawierać przynajmniej jedno prawo ogólne oraz musi mieć treść empiryczną (Filozofia a nau$k a \ldots$.. 1987, s. 747).

Rozpatrując rolę oraz zastosowanie różnych typów wyjaśniania należy pamiętać o tym, że nie każde wyjaśnienie naukowe oparte jest na tzw. prawdzie uniwersalnej (ogólnej). Szczególnie często zdarza się to $\mathrm{w}$ naukach społecznych, gdzie w porównaniu do nauk przyrodniczych istnieje stosunkowo niewiele uniwersalnych generalizacji. Dlatego też $w$ naukach tych szeroko stosowane jest wyjaśnianie probabilistyczne 5 . Mamy z nim do czynienia wtedy, gdy eksplanans zawiera przynajmniej jedno prawo probabilistyczne. $\mathrm{W}$ istocie jest ono jednak tylko jednym $\mathrm{z}$ rozszerzeń klasycznego modelu

${ }^{4} \mathrm{~W}$ literaturze przedmiotu znaleźć można wiele klasyfikacji i typologii wyjaśniania oraz charakterystyk ich przydatności dla różnych dyscyplin nauki. Szeroką charakterystykę podstawowych form wyjaśniania naukowego przedstawili M. WASZCZYK i E. SZCZERBINKI (2003, s. 10-13).

${ }^{5}$ Według niektórych autorów prawdopodobieństwo stało się wręcz fundamentalnym pojęciem nauki w XXI w. (NEKRAŠAS 1992, s. 239). 
wyjaśniania, które wynika z tego, że w naukach empirycznych - oprócz praw jednoznacznych - występują także prawa statystyczne, mówiące o tym, że wystąpienie zdarzeń określonego rodzaju jest prawdopodobne, jeśli wystąpią zdarzenia innego rodzaju. Wyjaśnianie probabilistyczne odwołuje się więc do uogólnień wyrażających albo arytmetyczny stosunek jednego zjawiska do drugiego ( $n$ procent $X=\eta$ ), albo do uogólnień wyrażających określone tendencje/skłonności ( $X$ ma skłonność do wywoływania $Y$ ).

Tab. 1. Rodzaje wyjaśniania oraz ich zastosowanie

\begin{tabular}{|c|c|c|c|}
\hline $\begin{array}{c}\text { Rodzaje } \\
\text { wyjaśniania }\end{array}$ & $\begin{array}{c}\text { Podstawowe } \\
\text { pojęcia }\end{array}$ & $\begin{array}{c}\text { Podstawowe } \\
\text { pytania }\end{array}$ & Zastosowanie \\
\hline Teleologiczne & cel - środek & „po co?” & $\begin{array}{l}\text { - Myślenie potoczne } \\
\text { - W psychologii - teoria racjonal- } \\
\text { nych decyzji }\end{array}$ \\
\hline Intencjonalne & znak-znaczenie & $\begin{array}{l}\text { "co on chciał przez to } \\
\text { powiedzieć?" }\end{array}$ & $\begin{array}{l}\text { - Hermeneutyka, interpretacje } \\
\text { tekstu } \\
\text { - Niegdyś dominujący rodzaj } \\
\text { przyczynowości (odczytywanie } \\
\text { znaków, przekazów, intencji) } \\
\end{array}$ \\
\hline Przyczynowe & przyczyna - skutek & „dlaczego?” & $\begin{array}{l}\text { - Nauki przyrodnicze (fizyka, } \\
\text { chemia) } \\
\text { - W psychologii - większość wy- } \\
\text { jaśnień } \\
\text { - Większość dyscyplin nauk spo- } \\
\text { lecznych i humanistycznych } \\
\text { (dodał W.A) }\end{array}$ \\
\hline Funkcjonalne & struktura - funkcja & $\begin{array}{l}\text { "jaką rolę pełni?", } \\
\text { „co mu to załatwia?" }\end{array}$ & $\begin{array}{l}\text { - Biologia i nauki przyrodnicze, } \\
\text { teoria ewolucji, teoria systemów } \\
\text { - Funkcjonalizm w socjologii } \\
\text { - Ewolucyjne orientacje w psy- } \\
\text { chologii }\end{array}$ \\
\hline Genetyczne & sytuacja - geneza & $\begin{array}{l}\text {,jak do tego doszło?" } \\
\text {,jak to się stało?" }\end{array}$ & $\begin{array}{l}\text { - Historia } \\
\text { - Psychologia - narracyjne teorie } \\
\text { umysłu }\end{array}$ \\
\hline Nomotetyczne & $\begin{array}{l}\text { Zdarzenie - } \\
\text { prawidłowość }\end{array}$ & $\begin{array}{l}\text { "jakie prawo to } \\
\text { wyjaśnia?" }\end{array}$ & - Głównie nauki nomotetyczne \\
\hline
\end{tabular}

Źródło: opracowanie własne na podstawie: M. WASZCZYK i E. SZCZERBICKI (2003) oraz http:/ / hal. psych.uw.edu.pl/.

Najważniejszym ograniczeniem generalizacji probabilistycznych (indukcyjnych) jest to, że w porównaniu do praw ogólnych wnioski dotyczące konkretnych przypadków nie mogą zostać wyprowadzone z całkowitą pewnością. Jeżeli np. wiadomo, że w danym roku w wyjazdach turystycznych, 
połączonych z minimum jednym noclegiem poza miejscem zamieszkania brało udział $60 \%$ Polaków mających wykształcenie wyższe, to nie możemy wnioskować z całkowitą pewnością, że prawdopodobieństwo takiego wyjazdu w przypadku konkretnego Polaka legitymującego się wyższym wykształceniem wyniesie 6/10. Wynika to z faktu, że na zachowanie konkretnych osób wpływają inne - oprócz uwzględnionego tu poziomu wykształcenia czynniki. Osoba taka może np. być miłośnikiem gór oraz aktywnym członkiem jakiegoś stowarzyszenia turystycznego, co zwiększa prawdopodobieństwo uprawiania turystyki (mogą to być też wyjazdy wielokrotne). $Z$ drugiej strony, jeśli będzie to np. osoba niepełnosprawna, to prawdopodobieństwo jej wyjazdu wyraźnie się zmniejszy. W istocie istnieje ogromna liczba czynników determinujących aktywność turystyczną. W jednym z materiałów Światowej Organizacji Turystyki, w trzech grupach uwarunkowań (społeczno-ekonomiczne, psychologiczno-socjalno-kulturalne oraz techniczne) wyróżniono aż 133 czynniki wpływające na poziom i charakter aktywności turystycznej ludności (WTO 1977, cyt. za: ŁAZAREK 1999, s. 69).

\section{Wyjaśnianie przyczynowe a atrybucje}

Problematyka przyczynowości stanowi jeden z podstawowych problemów nauki od zarania jej dziejów. Już samo zdefiniowanie pojęcia "przyczyna” oraz sprecyzowanie jakiego rodzaju relacje zasługują na miano związków przyczynowo-skutkowych nastręcza dużych problemów i powoduje, że rozwijane są różne odmiany analizy przyczynowej. Pomijając dorobek tzw. nauki starożytnej ${ }^{6}$ należy stwierdzić, że podwaliny pod współczesne teorie w tym zakresie położyło kilku wybitnych filozofów, w tym zwłaszcza D. Hume, I. Kant oraz J.S. Mill. Pomimo to że ich poglądy w wielu elementach różniły się, to każdy z nich znacząco przyczynił się do rozwoju wiedzy o przyczynowości.

Zasadniczo można wyróżnić dwa podstawowe podejścia do kwestii przyczynowości. Pierwsze z nich nawiązuje do poglądów P.S. Laplace'a oraz

6 Na przykład Arystotelesa, któremu przypisuje się stworzenie teoretycznych podstaw filozoficznej koncepcji determinizmu, rozwijanych później przez Tomasza z Akwinu.

7 Podczas gdy dwaj pierwsi (a zwłaszcza D. Hume) uważali, że o przyczynowości można wnioskować tylko na podstawie uprzednio zdobytej wiedzy (płynącej $\mathrm{z}$ obserwacji badanych zjawisk), to S. Mill zauważył i twórczo rozwinął myśl, że jako przyczynę jesteśmy skłonni uznawać także niezaistnienie jakiegoś zjawiska. 
I. Newtona i nazywane jest koncepcją klasyczną. Zakłada, że między przyczyną a efektem istnieje jednoznaczny i jednokierunkowy stosunek, że przyczyna zawsze jest przyczyną a efekt - efektem. Koncepcji tej odpowiada podstawowy schemat: "ta sama przyczyna wywołuje ten sam efekt”. Natomiast druga koncepcja (nazywana nieklasyczną) opiera się na rozróżnieniu dwóch podstawowych typów związków przyczynowych, tzw. mocnych związków (które są tożsame z interpretacją w koncepcji klasycznej) oraz wolnych związków, które uwzględniają nie tylko stosunki jednokierunkowe, lecz także oddziaływania pomiędzy przyczyną a skutkiem. Oznacza to, że istnieją sytuacje, w których przyczyna oraz efekt (skutek) mogą zamienić swoje pozycje i funkcje, przy czym może do tego dochodzić zarówno synchronicznie, jak i diachronicznie. W tej drugiej koncepcji dopuszcza się więc istnienie innych rodzajów zależności przyczynowych, gdzie (SCHENK 2008, s. 15):

- ,jedna przyczyna $\rightarrow$ wiele efektów",

- "wiele przyczyn $\rightarrow$ jeden efekt”,

- „wiele przyczyn $\rightarrow$ wiele efektów”.

Scharakteryzowane wyżej dwa odmienne podejścia do kwestii przyczynowości powodują, że na tle definiowania i rozumienia pojęcia przyczyn rodzi się wiele nieporozumień i niejasności ${ }^{8}$. Jedną z często cytowanych jest definicja T. Kotarbińskiego, według którego przyczyna to istotny składnik warunku wystarczającego oznaczający, że „zdarzenie $B$ jest skutkiem wcześniejszej odeń zmiany $A$, wypełniającej chwilę $t$, a zmiana $A$ - przyczyną zdarzenia $B$, zawsze i tylko, jeżeli zmiana $A$ jest składnikiem istotnym warunku wystarczającego zdarzenia B ze względu na chwilę t i ze względu na jakąś przyrodzoną prawidłowość następstwa zdarzeń" (KOTARBIŃSKI 1965, s. 27). Ow istotny składnik warunku wystarczającego, to takie zdarzenie składowe owego warunku, bez którego układ pozostałych jego zdarzeń składowych nie byłby warunkiem wystarczającym. Z definicji tej wynika, że uwarunkowania przyczynowe, to szczególny rodzaj związków między zdarzeniami, rozumianymi jako posiadanie jakiejś cechy przez określony przedmiot, pozostawanie przedmiotu w określonym stanie, zmiana cech przed-

${ }^{8}$ Jako przykład z dziedziny turystyki może posłużyć zaobserwowana przeze mnie kiedyś historia, w której o przyczynach tego, że dwunastoletni Krzysztof nie pojechał na wycieczkę w góry zupełnie inaczej wypowiadali się jego rodzice, nauczyciel oraz on sam. Krzysztof twierdzit, że przyczyną było to, że rodzice nie wyrazili zgody na wyjazd. Rodzice twierdzili, że przyczyną braku wyjazdu była ich obawa o zdrowie dziecka, gdyż ich zdaniem pogoda była nieodpowiednia, a słyszeli o wielu wypadkach w czasie górskich wycieczek. Natomiast nauczyciel, będący organizatorem wyjazdu stwierdził, że Krzysztof nie podołałby trudom górskiej wędrówki. Jak widać, każda z osób podała inna przyczynę braku wyjazdu.

72 WARSZTATY Z GEOGRAFII TURYZMU 
miotu, zachodzenie relacji między przedmiotami bądź zmiana relacji zachodzących między przedmiotami (KARPIŃSKI 1985, s. 17). Warto dodać, że oprócz zdarzeń, uwarunkowania przyczynowe mogą zachodzić także pomiędzy cechami oraz pomiędzy zmiennymi.

Rozważania nad determinacją i przyczynowością zjawisk społecznych są łatwiejsze od czasu, gdy J.S. Mill sformułował kilka zasad ujawniania się i weryfikacji związków przyczynowo-skutkowych, znanych jako „kanony Milla" (za: MORAWSKI 2000, s. 159):

1) kanon jedynej zgodności: Jeśli w zaobserwowanych przypadkach zdarzenie $Y$ występuje zawsze wspólnie ze zdarzeniem $X$ lub jest przez nie poprzedzane, a inne zdarzenia współwystępujące lub poprzedzające zdarzenie $Y$ czasem występowały a czasem nie, to zdarzenie $X$ jest prawdopodobnie przyczyną zdarzenia $Y$;

2) kanon jednej różnicy: Jeśli $z$ obserwacji wynika, że zdarzenie $Y$ wystąpiło wtedy, gdy równocześnie lub przedtem nastąpiło zdarzenie $X$, a następnie gdy - przy niezmienionym układzie innych zdarzeń - zdarzenie $X$ nie wystąpiło oraz nie wystąpiło też zdarzenie $Y$, to (prawdopodobnie) zdarzenie $X$ jest przyczyną zdarzenia $Y$;

3) kanon zmian towarzyszących: Jeśli w zaobserwowanych przypadkach nasilenie zdarzenia $Y$ zmieniało się, gdy przy niezmienionym układzie innych zdarzeń zmieniało się równocześnie nasilenie zdarzenia $X$, to (prawdopodobnie) zjawiska $X$ i $Y$ pozostają w związku przyczynowym;

4) kanon reszty: Jeśli zdarzenia $X_{1} \ldots X_{n}$ tworzą zamknięty (prawdopodobnie) zbiór przyczyn, wystarczających dla pojawienia się zdarzenia $Y$, a z poczynionych obserwacji wynika, że zdarzenia $X_{1} \ldots X_{n-1}$ nie mogą być uznane za przyczynę konieczną do pojawienia się zdarzenia $Y$, to (prawdopodobnie) zdarzenie $X_{n}$ jest przyczyną konieczną zdarzenia $Y$.

Pomimo to że kanony Milla stanowią ważny instrument wyjaśniania przyczynowości, mają one jednak ograniczoną wiarygodność, gdyż w praktyce badawczej nigdy nie jesteśmy w stanie spełnić wszystkich warunków, jakie przyjęto $\mathrm{w}$ założeniach. $\mathrm{Z}$ tego względu przytoczone kanony, które powstały na gruncie logiki, prowadzą nas jedynie do prawdopodobnych wniosków i jako takie powinny być zawsze uzupełniane innymi narzędziami (np. rachunkiem prawdopodobieństwa). Zwłaszcza gdy chodzi o badania dotyczące zachowań ludzi, które w mniejszym lub większym stopniu opierają się tylko na atrybucjach, traktowanych jednak jako przyczyny i tak 
zresztą w badaniach określanych. Dlatego też zanim przejdziemy do dalszych rozważan, należy wyraźnie podkreślić różnice pomiędzy przyczynami a atrybucjami oraz wyjaśnić najważniejsze teorie, które ich dotyczą.

Przede wszystkim należy pamiętać o tym, że teorie atrybucji zasadniczo nie wnikają (lub wnikają tylko pośrednio) w rzeczywiste przyczyny danego zachowania, lecz koncentrują się na spostrzeganych przyczynach takiego a nie innego zachowania. Inaczej mówiąc, przedmiotem badań nad atrybucjami są mechanizmy działania tzw. zdrowego rozsądku, czyli to, jak przeciętny człowiek (często nazywany w literaturze naiwnym badaczem) wyjaśnia zdarzenia, a także konsekwencje takich wyjaśnień. Wynika więc z tego, że podstawowy przedmiot analiz zaprezentowanych w dalszej części tego opracowania, czyli badania nad atrybucjami dotyczącymi braku aktywności turystycznej, w istocie nie dotyczy faktycznego wpływu poszczególnych czynników na podjęcie tej aktywności (lub jej braku), a jedynie ich opinii na temat tego, dlaczego jej nie podjęli.

\section{Inhibitory aktywności turystycznej jako atrybucje przyczynowe braku uczestnictwa $w$ turystyce $w$ świetle badań nad wyjazdami Europejczyków w latach 1997-2014}

Atrybucja, czyli przypisywanie ludzkim zachowaniom różnych przyczyn (zewnętrznych lub wewnętrznych), stanowi stosunkowo młody obszar naukowych rozważan, który zapoczątkowano dopiero w drugiej połowie XX wieku, kiedy podstawowe kanony teorii atrybucji stworzył Fritz Heider (cyt. za: FÖRSTERLING 2005, s. 18-20). Jest to o tyle dziwne, że atrybucje mają prawdopodobnie tak długą historię jak sama ludzkość, gdyż ludzie zawsze starali się analizować przyczyny swoich zachowań, a także badać i ustalać przyczyny różnorodnych zdarzeń (np. śmierci, wojny, powodzenia w szkole, w biznesie).

Również problematyka tzw. ekskluzji turystycznej, a zwłaszcza odrębne badania dotyczące braku uczestnictwa w turystyce oraz jego przyczyn, podejmowane są od niedawna i raczej rzadko, co - jak pisze J.V. HAUKENLAND (1990) w swojej pracy Non-travellers: The flip side of motivation - nie tylko zawęża pole analiz naukowych, ale także ogranicza ich wykorzystanie w praktycznej działalności na rynku turystycznym. Jest w tym stwierdzeniu dużo racji, gdyż wiele wskazuje na to, że oficjalne badania na temat aktyw- 
ności turystycznej ludności - ze względu na poważne mankamenty metodologiczne - często bardziej zaciemniają, niż rozjaśniają obraz sytuacji jeśli chodzi o zjawisko ekskluzji turystycznej.

W niniejszej pracy, oprócz wykazania dużych zróżnicowań pomiędzy mieszkańcami różnych krajów w zakresie deklarowanych przyczyn nieuczestniczenia $\mathrm{w}$ turystyce, postawiono także tezę, że szersze wykorzystanie $\mathrm{w}$ badaniach wiedzy na temat teorii atrybucji może pomóc w lepszym wyjaśnianiu faktycznych przyczyn braku uczestnictwa w turystyce. Zasadniczo można wyróżnić dwie podstawowe grupy teorii związanych $\mathrm{z}$ atrybucjami przyczynowymi: teorie atrybucji (attribution theories), które dotyczą czynników i sytuacji poprzedzających zachowania oraz prowadzą do różnych wyjaśnień przyczynowych, jak również teorie atrybucyjne (attributional theories), które dotyczą konsekwencji (głównie psychologicznych) atrybucji (KELLY, MiCHELA 1980, s. 45-50). Wydaje się, że pewien potencjał w tym zakresie mają obie grupy teorii atrybucji, które - poprzez dostarczenie wiedzy na temat mechanizmów wnioskowania o przyczynach określonych zachowań oraz konsekwencji atrybucji - mogłyby przyczynić się do udoskonalenia metodologii badań nad zjawiskiem ekskluzji turystycznej (np. ograniczyć błędy dotyczące atrybucji przyczynowych, takie jak efekt fałszywej powszechności; błąd korespondencji czy atrybucje egotystyczne, a także zwrócić uwagę na inne z pozoru mało istotne czynniki, które mogą mieć wpływ na deklaracje dotyczące przyczyn braku wyjazdów turystycznych).

Podstawę analiz zaprezentowanych $\mathrm{w}$ dalszej części pracy stanowią wyniki różnych badań, którymi objęto mieszkańców Polski oraz 34 innych krajów europejskich w okresie od 1997 do 2014 roku. W odniesieniu do Polski wykorzystano badania Instytutu Turystyki (IT), Głównego Urzędu Statystycznego (GUS) oraz Centrum Badania Opinii Społecznej (CBOS). Wzięto pod uwagę także wyniki własnych badań wykonanych do projektu „Funkcjonalna typologia uwarunkowań aktywności turystycznej”, realizowanego w ramach badań statutowych Akademii Wychowania Fizycznego w Krakowie. Do analizy zachowań mieszkańców pozostałych krajów europejskich wykorzystano wyniki kilku badań EUROSTAT-u prowadzonych w ramach projektu „Flash Eurobarometr".

W dyskusjach na temat przyczyn niewyjeżdżania na wypoczynek często przywołuje się znaną triadę: "nie mam gdzie, nie mam kiedy, nie mam za co" (JANKOWSKI 2006, s. 169). Sprawa jest jednak znacznie bardziej skomplikowana i wcale nie chodzi tu tylko o swoistą dezaktualizację dwóch pierwszych przyczyn, które w dobie ogromnej różnorodności ofert oraz ogólnej 
tendencji do wzrostu ilości czasu wolnego, utraciły pierwotne znaczenie. Obecnie przyczyn tych jest nie tylko coraz więcej, ale mają one także coraz bardziej złożony charakter, co - jak się wydaje - powinno znaleźć wyraz w metodologii badań nad aktywnością turystyczną, a przynajmniej w tej ich części, która ma na celu uchwycenie przyczyn jej braku. Tymczasem istnieje duża różnorodność stosowanych typologii i klasyfikacji przyczyn niewyjeżdżania9", co w dużym stopniu utrudnia zarówno analizy porównawcze, a czasami czyni je niemożliwymi do przeprowadzenia. Dodatkowo towarzyszą temu różnice liczby przyczyn niewyjeżdżania podawanych w kwestionariuszach. Na przykład w badaniach EUROSTAT stosuje się zwykle cztero- albo ośmioelementowy zakres przyczyn.

W większości typologii inhibitorów aktywności turystycznej podstawowa rola przypisywana jest barierom finansowym, niezależnie od tego, czy w ankiecie używa się sformułowania "niskie dochody”, „brak pieniędzy” czy "przyczyny finansowe” - co pokazują tab. 2 (badania IT) i 3 (badania GUS) oraz rys. 1 (badania CBOS).

W badaniach Instytutu Turystyki (tab. 2) uwzględniono wypowiedzi 3803 respondentów. Najczęściej wskazywali oni na przyczyny finansowe, a pozostałe czynniki miały zdecydowanie mniejsze (zaledwie kilkuprocentowe) znaczenie i zasadniczo dotyczyły podobnych wartości. W badaniach GUS (tab. 3) którymi objęto 4006 gospodarstw domowych oraz 12444 osoby, istotne różnice we wskazaniach dotyczyły także innych inhibitorów. Na przykład dużo częściej wyjeżdżano ze względu na stan zdrowia, przy czym - co dość zaskakujące - była to przyczyna, która częściej ograniczała uczestnictwo w wyjazdach krajowych niż zagranicznych. Zróżnicowania te nie zmieniają jednak faktu, że w badaniach wszystkich polskich instytucji najważniejszymi inhibitorami aktywności turystycznej - niezależnie, czy dotyczyło to uczestnictwa poszczególnych osób czy całych gospodarstw domowych oraz czy chodzi o wszystkie wyjazdy turystyczne, czy tylko o wyjazdy wypoczynkowe - są czynniki ekonomiczne (niskie dochody). Potwierdzają to także badania przeprowadzone przez Centrum Badania Opinii Społecznej (por. rys. 1).

${ }^{9} \mathrm{~W}$ literaturze światowej istnieje wiele klasyfikacji ograniczeń i barier aktywności turystycznej. Najczęściej cytowana jest typologia wyróżniająca sześć głównych barier w podróżowaniu: koszty (w znaczeniu duże koszty), brak czasu (w znaczeniu braku czasu wolnego), ograniczenia zdrowotne, czynniki rodzinne, obawa o bezpieczeństwo i brak zainteresowania wyjazdami turystycznymi (GOELDNER, RITCHIE 2006, s. 317).

76 WARSZTATY Z GeOGRAFII TURYZMU 
Tab. 2. Przyczyny nieuczestniczenia w długookresowych wyjazdach turystycznych w latach 2003-2005 - badania Instytutu Turystyki (\% odpowiedzi)

\begin{tabular}{|l|c|c|c|}
\hline \multicolumn{1}{|c|}{ Przyczyny braku wyjazdów } & 2003 r. & 2004 r. & 2005 r. \\
\hline $\begin{array}{l}\text { Ze względu na poziom zamożności nie stać mnie na wyjazd } \\
\text { urlopowo-wakacyjny }\end{array}$ & 52 & 52 & 52 \\
\hline Nie mogłem zostawić domu, rodziny bez opieki & 7 & 8 & 7 \\
\hline Nie miałem ochoty, nie jest mi to potrzebne & 7 & 7 & 7 \\
\hline Nie wyjechałem z przyczyn związanych z pracą zawodową & 6 & 6 & 7 \\
\hline Nie wyjechałem ze względu na swoją chorobę & 6 & 5 & 6 \\
\hline Nie wyjechałem, bo jestem w podeszłym wieku & 4 & 5 & 5 \\
\hline Nie mogłem zostawić gospodarstwa rolnego bez nadzoru & 5 & 5 & 4 \\
\hline $\begin{array}{l}\text { Zrezygnowałem z wyjazdu w związku z dużymi wydatkami (kupno } \\
\text { samochodu, mieszkania, budowa domu, duży remont itd.) }\end{array}$ & 3 & 3 & 4 \\
\hline Nie wyjechałem ze względu na prace domowe, np. remont, porządki & 3 & 3 & 3 \\
\hline $\begin{array}{l}\text { Nie miałem dokąd pojechać, nie miał mi kto zorganizować } \\
\text { wypoczynku }\end{array}$ & 2 & 2 & 2 \\
\hline Wykorzystałem urlop na dodatkową pracę zarobkową & 1 & 2 & 1 \\
\hline Nie wyjechałem, bo jestem inwalidą & 1 & 1 & 1 \\
\hline Inne & 3 & 1 & 1 \\
\hline
\end{tabular}

Źródło: J. ŁACIAK (2005, s. 24).

Można zastanowić się jednak, czy pomimo dominującego znaczenia przyczyn natury ekonomicznej, aż tak wielki odsetek wskazań nie jest przypadkiem zawyżany na skutek nie zawsze właściwie dobranego zestawu przyczyn poddawanych pod ocenę respondentów. Często zdarza się bowiem, że w kafeterii odpowiedzi, niektóre przyczyny są do siebie na tyle podobne, że zaklasyfikowanie ich do odpowiedniej kategorii może sprawiać respondentom trudności. $W$ takiej sytuacji może się zdarzyć, że będą oni przypisywać czynnikom najważniejszym większe znaczenie, niż ma to miejsce w rzeczywistości, na co zwracają uwagę niektórzy badacze (np. HAUKELAND 1984, s. 207-214).

Analizy metodologii badań nad aktywnością turystyczną prowadzone w kilkunastu krajach świata (ALEJZIAK 2009, s. 84-143) wykazały, że podstawową miarą $\mathrm{w}$ prawie wszystkich oficjalnych raportach jest liczba oraz odsetek osób lub gospodarstw domowych, które odbyły podróż. Uzyskane wartości zestawia się według różnych kryteriów, w zależności od celu badań i rodzajów planowanych analiz, a wykorzystuje się do tego głównie podstawowe metody statystyki opisowej, jedno- lub dwuelementowe tabele prezentujące uzyskane wyniki jedynie $w$ liczbach bezwzględnych i procentach. Bardzo rzadko stosuje się też tzw. testowanie hipotez statystycznych, które 


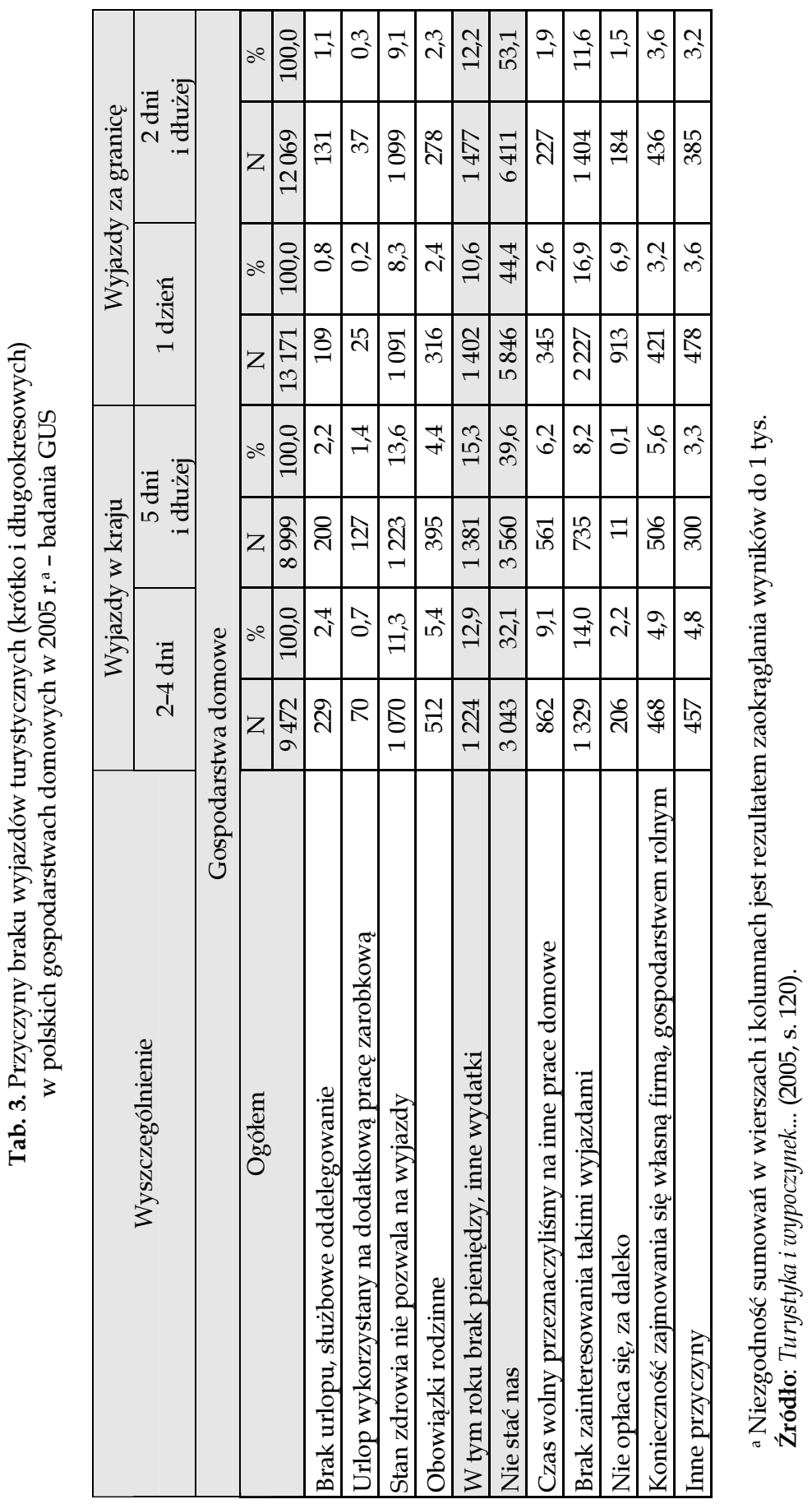


ma na celu sprawdzenie, w jakim stopniu wyniki uzyskane z próby są prawdopodobne i reprezentatywne dla całej populacji. W badaniach omnibusowych, wykonywanych w ramach tzw. statystyki publicznej i udostępnianych potem bezpłatnie, nie stosuje się bardziej zaawansowanych metod i technik, takich jak np. analiza skupień czy analiza czynnikowa.

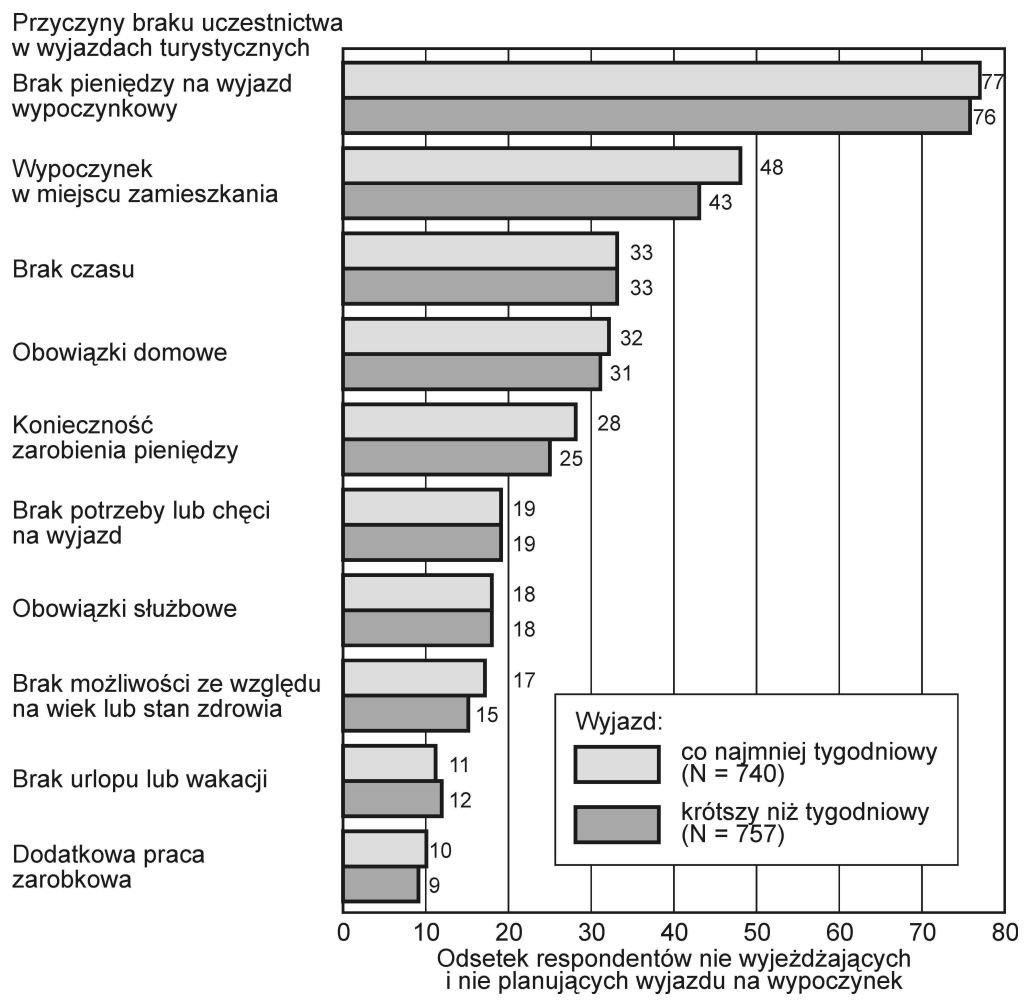

Rys. 1. Inhibitory wyjazdów wypoczynkowych Polaków w 2005 r.

Źródło: CBOS (2005, s. 7)

Podejrzewając, że ich zastosowanie mogłoby ukazać inny obraz sytuacji niż ten, który wyłania się z ogólnych zestawień procentowych, zakupiono bazę danych rzeczywistych od CBOS i przeprowadzono własne obliczenia, które ukazały wiele ciekawych zależności, w tym m.in. większe niż zazwyczaj się przypuszcza znaczenie czynników pozaekonomicznych (czynniki ekonomiczne zdecydowanie dominowały tylko w pierwszym skupieniu) (tab. 4, rys. 2). 
Tab. 4. Inhibitory wyjazdów wypoczynkowych - średnie w poszczególnych skupieniach

\begin{tabular}{|l|c|c|c|c|c|c|}
\hline \multirow{4}{*}{$\begin{array}{c}\text { Inhibitory } \\
\text { aktywności turystyczne }\end{array}$} & \multicolumn{3}{|c|}{$\begin{array}{c}\text { Wyjazdy na co najmniej } \\
\text { tygodniowy wypoczynek }\end{array}$} & \multicolumn{3}{c|}{$\begin{array}{c}\text { Wyjazdy na krótszy niż } \\
\text { tygodniowy wypoczynek }\end{array}$} \\
\cline { 2 - 7 } & $\begin{array}{c}\text { Skupienie } \\
1 .\end{array}$ & $\begin{array}{c}\text { Skupienie } \\
2 .\end{array}$ & $\begin{array}{c}\text { Skupienie } \\
3 .\end{array}$ & $\begin{array}{c}\text { Skupienie } \\
1 .\end{array}$ & $\begin{array}{c}\text { Skupienie } \\
2 .\end{array}$ & $\begin{array}{c}\text { Skupienie } \\
\text { N }\end{array}$ \\
& $N=166$ & $N=157$ & $N=452$ & $N=219$ & $N=142$ \\
\hline Brak pieniędzy & 0,843 & 0,741 & 0,631 & 0,896 & 0,658 & 0,528 \\
\hline Brak czasu & 0,061 & 0,590 & 0,879 & 0,082 & 0,863 & 0,254 \\
\hline $\begin{array}{l}\text { Brak możliwości (dobrej } \\
\text { oferty) }\end{array}$ & 0,193 & 0,253 & 0,025 & 0,144 & 0,078 & 0,338 \\
\hline Brak urlopu & 0,026 & 0,096 & 0,376 & 0,033 & 0,329 & 0,042 \\
\hline Obowiązki domowe & 0,065 & 0,873 & 0,484 & 0,095 & 0,694 & 0,366 \\
\hline Obowiązki służbowe & 0,012 & 0,114 & 0,726 & 0,022 & 0,548 & 0,056 \\
\hline Dodatkowa praca & 0,016 & 0,066 & 0,401 & 0,015 & 0,297 & 0,007 \\
\hline Zarobić pieniądze & 0,116 & 0,217 & 0,834 & 0,091 & 0,644 & 0,070 \\
\hline Brak potrzeby wyjazdu & 0,155 & 0,373 & 0,089 & 0,018 & 0,128 & 0,831 \\
\hline $\begin{array}{l}\text { Urlop w miejscu } \\
\text { zamieszkania }\end{array}$ & 0,338 & 0,867 & 0,522 & 0,259 & 0,534 & 0,831 \\
\hline
\end{tabular}

Źródło: opracowanie własne.

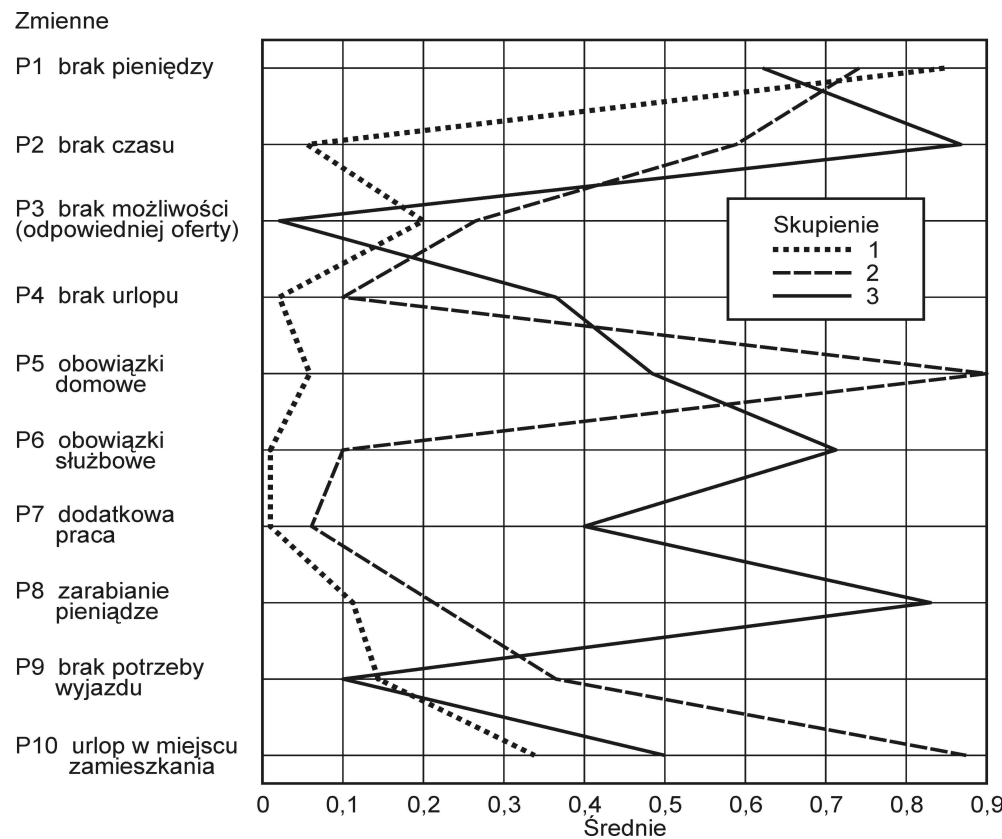

Rys. 2. Inhibitory wyjazdów na co najmniej tygodniowy wypoczynek - wartości średnich w skupieniach

Źródło: opracowanie własne 
Tezy o dużym zróżnicowaniu atrybucji przyczynowych dotyczących braku uczestnictwa w wyjazdach turystycznych oraz mniejszej niż zwycza-jowo się przyjmuje dominacji czynników ekonomicznych $w$ tym zakresie znajdują potwierdzenie $\mathrm{w}$ wynikach badań przeprowadzonych w 1997 roku pod auspicjami EUROSTAT-u w 15 krajach Unii Europejskiej, a także w badaniach prowadzonych przez tę instytucję $\mathrm{w}$ latach 2008-2015. Pierwsze ze wspomnianych badań wykazały, że udział przyczyn finansowych waha się od $67,5 \%$ w przypadku Portugalii do nieco ponad 30\% w Luksemburgu, Danii i Szwecji. Także pozostałym przyczynom przypisuje się różne znaczenie w poszczególnych krajach. Sprawy zawodowe uniemożliwiły wyjazd tylko kilku procentom Belgów i Brytyjczyków, co czwartemu Hiszpanowi (24,3\%) oraz prawie co trzeciemu mieszkańcowi Grecji (31,9\%). Natomiast na sprawy osobiste najczęściej wskazywali Włosi i Austriacy, a najrzadziej Finowie i Brytyjczycy (tab. 5).

Tab. 5. Przyczyny niewyjeżdżania na wakacje w 1997 r. - badania EUROSTAT-u (w \% odpowiedzi)

\begin{tabular}{|l|c|c|c|c|c|}
\hline \multicolumn{1}{|c|}{ Kraj } & Wyjeżdżający* & $\begin{array}{c}\text { Przyczyny } \\
\text { finansowe }\end{array}$ & $\begin{array}{c}\text { Sprawy } \\
\text { zawodowe }\end{array}$ & $\begin{array}{c}\text { Sprawy } \\
\text { osobiste }\end{array}$ & $\begin{array}{c}\text { Pozostałe } \\
\text { przyczyny }\end{array}$ \\
\hline 1. Francja & 49,3 & 55,1 & 20,8 & 19,7 & 10,5 \\
\hline 2. Austria & 41,5 & 42,9 & 22,6 & 28,3 & 5,7 \\
\hline 3. Belgia & 45,8 & 42,7 & 7,4 & 26,0 & 23,2 \\
\hline 4. Dania & 75,7 & 35,0 & 18,1 & 23,5 & 14,6 \\
\hline 5. Finlandia & 65,4 & 44,7 & 19,2 & 12,1 & 16,6 \\
\hline 6. Grecja & 42,4 & 57,8 & 31,9 & 23,1 & 7,9 \\
\hline 7. Hiszpania & 47,4 & 52,6 & 24,3 & 23,7 & 9,7 \\
\hline 8. Holandia & 71,0 & 47,4 & 10,2 & 16,5 & 18,0 \\
\hline 9. Irlandia & 39,9, & 48,1 & 13,0 & 19,5 & 17,2 \\
Irlandia Płn. & 36,9 & 58,9 & 11,5 & 19,3 & 9,4 \\
\hline 10. Luksemburg & 63,9 & 30,9 & 12,1 & 26,6 & 19,3 \\
\hline 11. Niemcy Wsch.) & 50,0 & 48,0 & 11,6 & 25,9 & 5,4 \\
Niemcy (Zach.) & 52,1 & 51,0 & 15,0 & 29,4 & 3,4 \\
\hline 12. Portugalia & 32,1 & 67,5 & 14,3 & 20,1 & 8,2 \\
\hline 13. Szwecja & 69,1 & 36,1 & 17,0 & 18,4 & 23,3 \\
\hline 14. Wielka Brytania & 55,4 & 60,9 & 8,4 & 13,1 & 13,1 \\
\hline 15. Włochy & 52,0 & 34,2 & 17,5 & 33,1 & 13,4 \\
\hline
\end{tabular}

* W pierwszej kolumnie podano informacje o udziale \% wyjeżdżających, co oznacza, że takiej części respondentów w danym kraju pytanie o przyczyny niewyjeżdżania nie dotyczyło.

Źródło: opracowanie własne na podstawie: Eurobarometer 48.0 (1997). 
Przez długi czas badania dotyczące aktywności turystycznej prowadzone w skali międzynarodowej oraz przy zastosowaniu podobnej metodologii należały do rzadkości, co bardzo utrudniało dokonywanie analiz porównawczych $^{10}$. W końcu pierwszej dekady XXI wieku zaszła w tym względzie jednak zasadnicza zmiana i badania takie zostały włączone w zakres cyklicznych badań EUROSTAT „Flash Eurobarometr". Decyzja o corocznym ich prowadzeniu na tak szeroko zakrojoną skalę znakomicie zwiększyła wiedzę na temat poziomu, struktury i uwarunkowań aktywności turystycznej Europejczyków oraz poszerzyła możliwości dokonywania porównań międzynarodowych (ALEJZIAK 2011, s. 7-16). Badania te prowadzone są bowiem na reprezentatywnych próbach mieszkańców poszczególnych krajów o różnej liczebności ludności ${ }^{11}$, co oznacza, że za każdym razem uzyskuje się odpowiedzi od ponad 30 tys. respondentów z prawie wszystkich krajów europejskich.

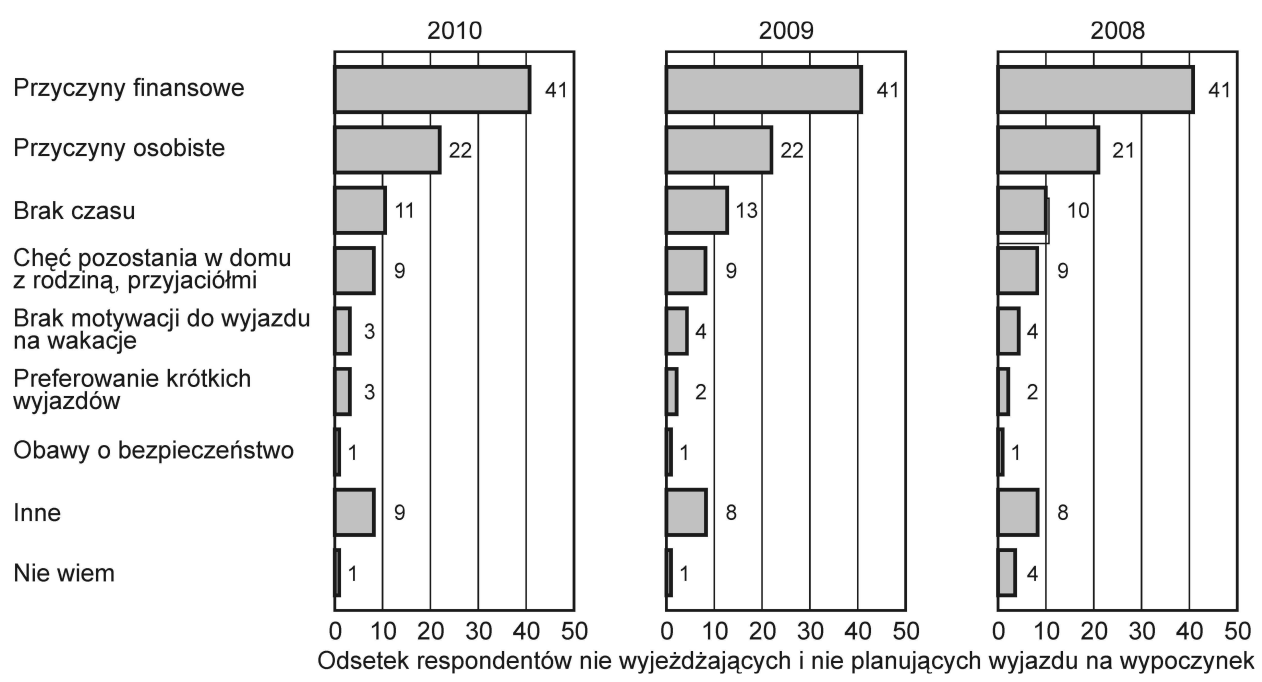

Rys. 3. Główne przyczyny braku uczestnictwa w wyjazdach turystycznych mieszkańców Europy w latach 2008-2010

Źródło: Eurobarometer (2011, s. 17).

${ }^{10}$ Właściwie badania takie (tzn. prowadzone w jednym czasie i przy użyciu tej samej metodologii przeprowadzono w UE tylko dwa razy: w 1988 r. (w 12 krajach ówczesnej EWG) oraz w 1997 r. (w 15 krajach tzw. starej UE).

${ }^{11}$ Wielkość próby uzależniona była od populacji danego kraju - w większości krajów wynosiła 1500 lub 1000 respondentów. W przypadku Niemiec próba jest zawsze nieco większa (ponad 2000 respondentów), zaś w przypadku mniejszych krajów (takich jak Malta, Litwa, Łotwa, Estonia, Słowenia, Cypr czy Luksemburg) próby liczą zwykle po 500 osób.

82 WARSZTATY Z GEOGRAFII TURYZMU 
Już pierwszy raport $\mathrm{z}$ badań realizowanych według tej nowej formuły sygnalizował zmianę podejścia i pewnych założeń metodologicznych jeśli chodzi o uwarunkowania aktywności turystycznej, w tym także kwestii analizowania przyczyn braku wyjazdów. Przede wszystkim - w porównaniu do badań wcześniejszych - zwiększono kafeterię odpowiedzi dotyczących przyczyn braku uczestnictwa $w$ wyjazdach turystycznych $\mathrm{z}$ czterech (jak $w$ badaniach z 1997 r.) do ośmiu. Pierwsze trzy sondaże wykazały rosnące zróżnicowanie wskazywanych przez respondentów przyczyn nieuczestniczenia $\mathrm{w}$ turystyce $\mathrm{w}$ skali całej Unii Europejskiej, ale także różnice jakie w tym względzie zachodziły pomiędzy mieszkańcami poszczególnych krajów. Na rys. 3 pokazano najważniejsze inhibitory aktywności turystycznej w latach 2008-2010.

Niestety w kolejnych badaniach nie zawsze zachowano ten sam układ ankiety oraz ten sam zestaw możliwych do wskazania przyczyn, co nieco ograniczyło możliwości porównań. Jak widać na rys. 4, w badaniach z 2012 i 2013 roku nie tylko wprowadzono nową kategorię (nieuczestnictwo z powodu pracy/kariery zawodowej), ale także inaczej odniesiono się do kwestii bezpieczeństwa oraz dostępności usług transportowych i noclegowych.

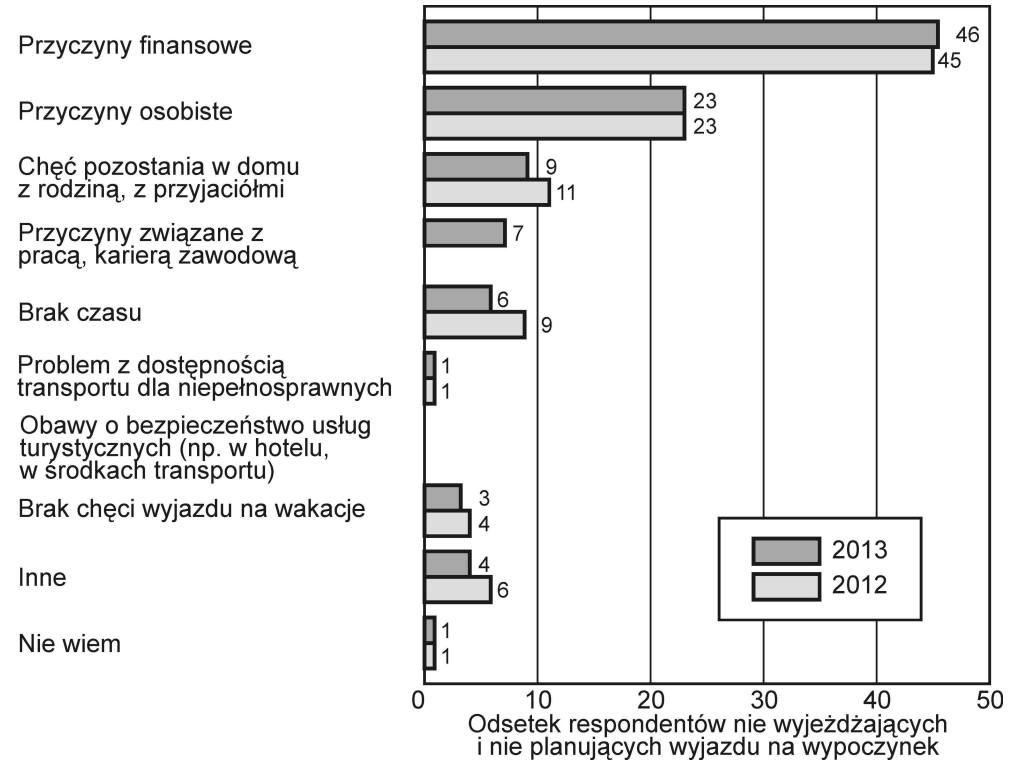

Rys. 4. Przyczyny braku uczestnictwa w wyjazdach turystycznych mieszkańców Europy w latach 2012-2013

Źródło: Eurobarometer (2013, s. 58) 

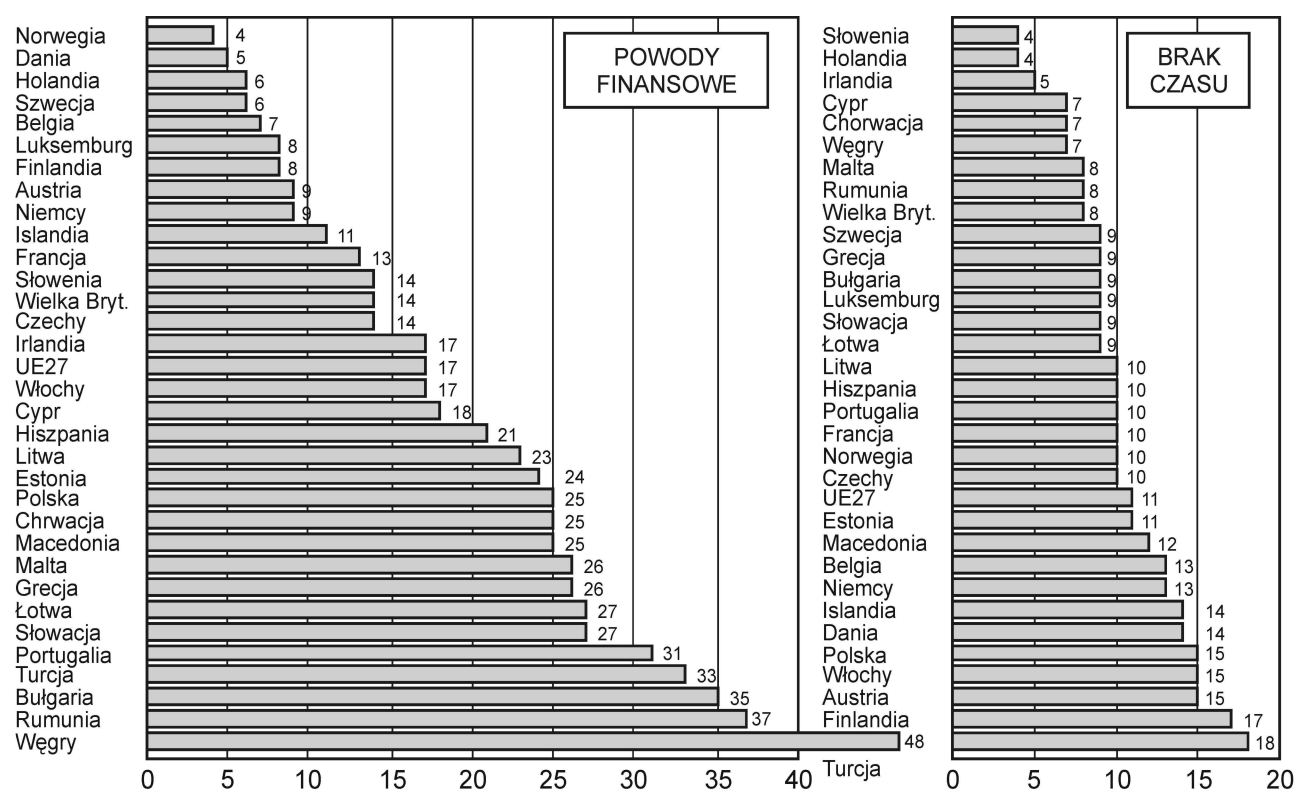

Łotwa

Norwegia

Bułgaria

Litwa

Rumunia

Islandia

Finlandia

Portugalia

Szwecja

Irlandia

Estonia

Malta

Grecja

Cypr

Słowacja

Polska

Słowenia

Wielka Bryt.

Hiszpania

Holandia

UE27

Francja

Turcja

Dania

Macedonia

Belgia

Austria

Czechy

Niemcy

Chorwacja

Luksembu

Włochy

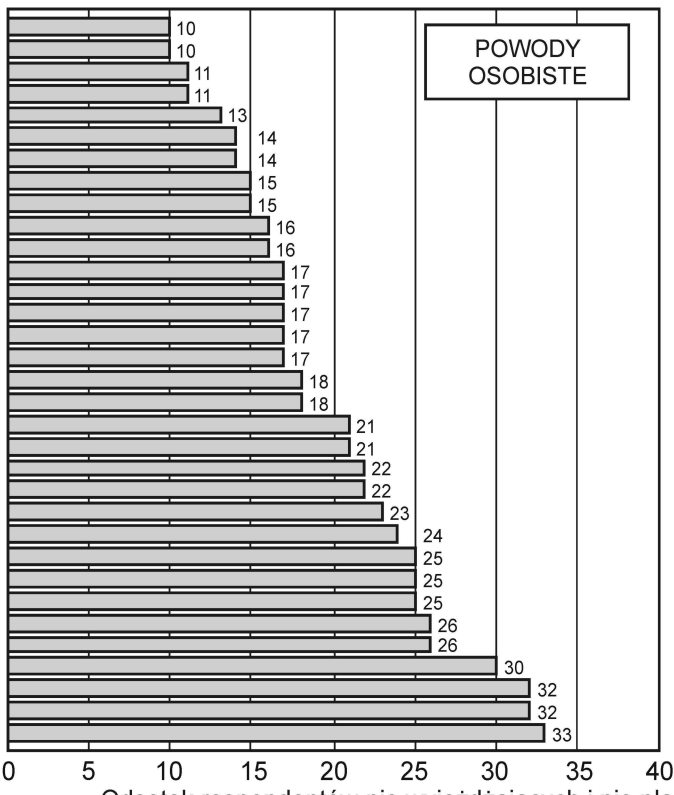

Macedonia

Cypr

Chorwacja

Łotwa

Węgry

Portugalia

Bułgaria

Holandia

Islandia

Litwa

Grecja

Włochy

Polska

UE27

Słowenia

Hiszpania

Francja

Estonia

Niemcy

Słowacja

Wielka

Czechy

Norwegia

Dania

Szwecja

Luksembur

Irlandia

Belgia

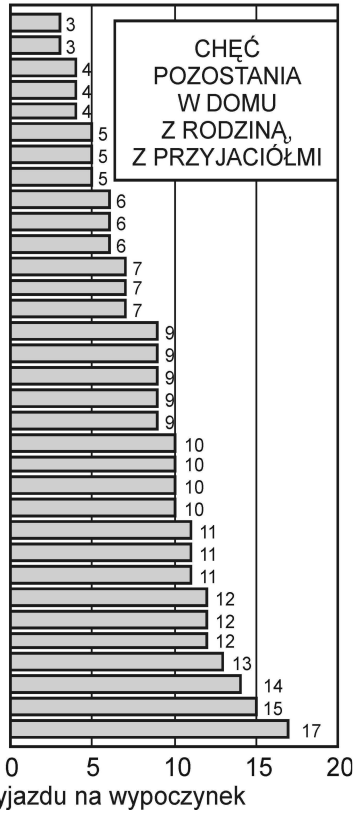

Rys. 5. Przyczyny braku uczestnictwa w wyjazdach turystycznych

mieszkańców Europy według krajów w 2010 r.

Źródło: opracowanie własne na podstawie: Eurobarometer (2011, s. 18-20)

84 WARSZTATY Z GEOGRAFII TURYZMU 
Warto jednak zauważyć, że problematyce przyczyn braku uczestnictwa $\mathrm{w}$ turystyce nadano większą rangę, o czym świadczy liczba analiz oraz poziom szczegółowości interpretacji dotyczących tego zagadnienia. Taka sama metodologia badań oraz jednolity sposób prezentacji materiału w kolejnych raportach bardzo ułatwiły dokonywanie porównań dynamicznych oraz międzynarodowych, które - co warto podkreślić - objęły także niektóre kraje spoza Unii Europejskiej (już w raporcie z 2011 r. badaniami objęto 32 kraje, a w 2014 r. dodatkowo uwzględniono także Izrael). W raporcie tym znajdziemy także bardzo czytelne zestawienia ilustrujące skalę zróżnicowań międzynarodowych dotyczących atrybucji $\mathrm{w}$ zakresie przyczyn nieuczestniczenia $\mathrm{w}$ turystyce występujących w poszczególnych krajach, co pokazuje rys. 5 . Warto zauważyć, że $\mathrm{w}$ niektórych przypadkach zróżnicowanie, jakie w zakresie wskazywanych przyczyn braku uczestnictwa w turystyce występuje pomiędzy mieszkańcami poszczególnych krajów, sięga kilkuset procent. Warto też dodać, że podobne (a czasami jeszcze większe) zróżnicowania dotyczyczy mogą reprezentantów różnych grup społecznych wyodrębnianych na podstawie tzw. zmiennych metryczkowych.

Przedstawione dotychczas dane, a także wskazane na ich podstawie tendencje dotyczące zróżnicowania poziomu aktywności turystycznej oraz atrybucji przyczyn jej braku potwierdza ostatni raport EUROSTAT, który został

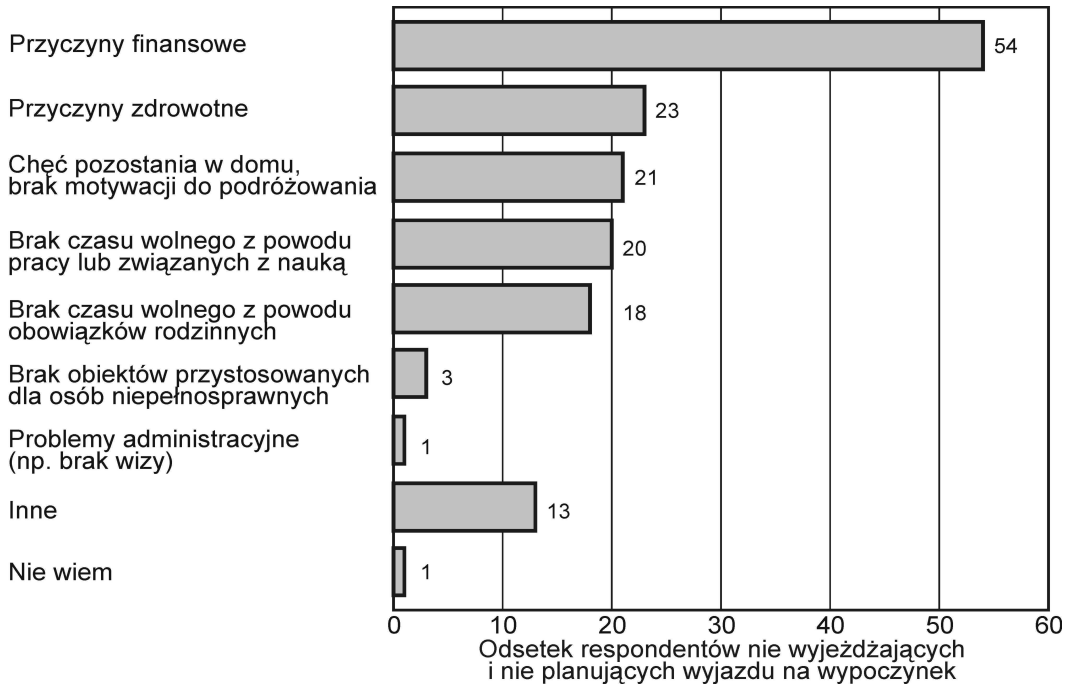

Rys. 6. Główne przyczyny braku uczestnictwa w wyjazdach turystycznych mieszkańców Europy w 2014 r.

Źródło: opracowanie własne na podstawie: Eurobarometer (2015, s. 62) 


\begin{tabular}{|c|c|c|c|c|c|c|c|c|c|}
\hline & \multirow[b]{2}{*}{$\begin{array}{l}\text { PROBLEMY } \\
\text { FINANSOWE }\end{array}$} & \multirow[b]{2}{*}{$\begin{array}{l}\text { PROBLEMY } \\
\text { ZDROWOTNE }\end{array}$} & \multirow{2}{*}{$\begin{array}{c}\text { PREFEROWANIE } \\
\text { POBYTU W DOMU } \\
\text { BRAK MOTYWACJI } \\
\text { PODO } \\
\text { PODOZZWWANIA }\end{array}$} & \multicolumn{2}{|c|}{ BRAK CZASU WOLNEGO } & \multirow{2}{*}{$\begin{array}{c}\text { BRAK } \\
\text { UDOGODNIEN } \\
\text { DLANIEPE } \text { SNO- } \\
\text { SPRAWNYCH }\end{array}$} & \multirow{2}{*}{$\begin{array}{c}\text { PROBLEMY } \\
\text { ADMINISTR. } \\
\text { (NP.BRAK } \\
\text { WIZY) }\end{array}$} & \multirow[b]{2}{*}{ INNE } & \multirow[b]{2}{*}{$\begin{array}{l}\text { NIE } \\
\text { WIEM }\end{array}$} \\
\hline & & & & $\begin{array}{c}\text { OBOWIAZKI } \\
\text { ZAWODOWW } \\
\text { SZKOLNE }\end{array}$ & $\begin{array}{l}\text { OBOWIAZKI } \\
\text { RODZINNE }\end{array}$ & & & & \\
\hline EU 28 & 42 & 15 & 13 & 13 & 10 & 1 & & 5 & 1 \\
\hline Belgia & 25 & 18 & 26 & 14 & 9 & 2 & & 5 & 1 \\
\hline Bułgaria & 53 & 14 & 8 & 13 & 8 & 1 & & 2 & 1 \\
\hline Czechy & 34 & 23 & 11 & 13 & 11 & 1 & & 7 & \\
\hline Dania & 27 & 18 & 22 & 16 & 5 & 1 & & 9 & 2 \\
\hline Niemcy & 21 & 24 & 16 & 19 & 9 & 1 & & 8 & 2 \\
\hline Estonia & 45 & 22 & 10 & 12 & 3 & 1 & & 5 & 2 \\
\hline Irlandia & 42 & 9 & 17 & 10 & 15 & 2 & & 5 & \\
\hline Grecja & 65 & 7 & 6 & 11 & 7 & 1 & & 3 & \\
\hline Hiszpania & 55 & 10 & 12 & 11 & 6 & 1 & & 5 & \\
\hline Francja & 38 & 18 & 15 & 14 & 9 & 1 & & 5 & \\
\hline Chorwacja & 58 & 9 & 8 & 11 & 8 & 1 & 1 & 4 & \\
\hline Włochy & 47 & 11 & 12 & 12 & 12 & 1 & & 4 & 1 \\
\hline Cypr & 57 & 12 & 9 & 7 & 8 & & & 6 & 1 \\
\hline Łotwa & 45 & 10 & 9 & 19 & 11 & 2 & 1 & 3 & \\
\hline Litwa & 33 & 19 & 6 & 17 & 6 & 1 & & 17 & 1 \\
\hline Luksemburg & 29 & 19 & 20 & 14 & 7 & 2 & & 8 & 1 \\
\hline Węgry & 57 & 13 & 6 & 10 & 9 & 1 & & 4 & \\
\hline Malta & 29 & 13 & 14 & 20 & 10 & & & 11 & 3 \\
\hline Holandia & 39 & 18 & 22 & 6 & 5 & 1 & & 9 & \\
\hline Austria & 24 & 18 & 25 & 14 & 12 & & & 5 & 2 \\
\hline Polska & 43 & 13 & 9 & 15 & 14 & 1 & & 5 & \\
\hline Portugalia & 59 & 8 & 8 & 13 & 7 & & & 4 & 1 \\
\hline Rumunia & 57 & 11 & 4 & 14 & 10 & 1 & 1 & 2 & \\
\hline Słowenia & 39 & 18 & 19 & 5 & 10 & & & 7 & 2 \\
\hline Słowacja & 46 & 15 & 8 & 11 & 9 & 1 & 1 & 8 & 1 \\
\hline Finlandia & 29 & 16 & 27 & 16 & 7 & 1 & & 3 & 1 \\
\hline Szwecja & 23 & 22 & 31 & 6 & 3 & & & 12 & 3 \\
\hline Wielka Bryt. & 35 & 18 & 17 & 12 & 10 & 3 & & 5 & \\
\hline Macedonia & 64 & 12 & 5 & 8 & 8 & & & 1 & 2 \\
\hline Islandia & 21 & 12 & 17 & 26 & 4 & 1 & & 15 & 4 \\
\hline Czarnogóra & 51 & 17 & 6 & 12 & 11 & & & 3 & \\
\hline Turcja & 42 & 9 & 11 & 20 & 14 & & 1 & 3 & \\
\hline Mołdawia & 58 & 9 & 3 & 19 & 6 & & 1 & 3 & 1 \\
\hline
\end{tabular}

Rys. 7. Przyczyny braku uczestnictwa w wyjazdach turystycznych mieszkańców Europy według krajów w 2014 r.

Źródło: opracowanie własne na podstawie Eurobarometer (2015, s. 61)

opublikowany w 2015 roku. Zaprezentowano w nim wyniki badań przeprowadzonych w 34 krajach. Okazało się, że w 2014 roku stopa aktywności turystycznej mieszkańców UE wyniosła $72 \%$, zaś biernych turystycznie pozostawało $26 \%$ Europejczyków, przy czym najwyższe wskaźniki aktywności dotyczyły Islandii - 90\%, Szwecji - 87\% i Luksemburga, a najniższe Macedonii - 30\%, Turcji - 50\%, Portugalii - 52\% (Eurobarometer 2015, s. 23-25). 
Jeśli chodzi o atrybucje przyczyn braku wyjazdów, to zgodnie z oczekiwaniami dominowały czynniki ekonomiczne, na które wskazało $54 \%$ badanych, którzy w 2014 roku w ogóle nie wyjeżdżali w celach turystycznych. Co ciekawe, badania wykazały, że odsetek wskazań przyczyn finansowych rośnie wtedy, gdy respondent ma możliwość wskazania kilku przyczyn braku wyjazdu (por. rys. 6) i maleje wtedy, gdy proszony jest o wskazanie kilku przyczyn (rys. 7).

Warto podkreślić, że aż w pięciu krajach czynniki ekonomiczne nie były tymi, które wskazywano najczęściej. Okazało się, że z przyczyn finansowych nie wyjechał zaledwie co piąty Niemiec i Islandczyk (w obu krajach taką przyczynę podało tylko 21\% respondentów). Pozostałe trzy kraje, w których czynniki finansowe nie były wymieniane w pierwszej kolejności, to Szwecja $(23 \%)$, Austria (24\%) i Belgia (25\%). Z kolei najwyższy odsetek wskazań czynników ekonomicznych dotyczył Grecji (65\%), którą jak wiadomo doświadcza bardzo poważny kryzys gospodarczy (Eurobarometer 2015, s. 61). Warto odnotować, że w tych krajach, gdzie przyczyny finansowe nie były najważniejsze - na pierwszym miejscu wskazywano albo preferowanie pobytu w domu i brak motywacji do wyjazdu (Szwecja 31\% wskazań, Belgia - 26\% i Austria - 25\%), brak czasu (Islandia - 25\%) lub przyczyny zdrowotne (Dania - 24\%). Pełny obraz sytuacji w zakresie zróżnicowań atrybucji dotyczących inhibitorów aktywności turystycznej przedstawia rys. 6 .

\section{Zakończenie}

Przeprowadzone analizy wykazały niedostatki metodologiczne prowadzonych dotychczas badań nad aktywnością turystyczną $\mathrm{w}$ tej części, która dotyczy identyfikacji przyczyn braku uczestnictwa w wyjazdach. Polegają one przede wszystkim na zbytniej dowolności doboru inhibitorów tej aktywności (przyczyn niewyjeżdżania), co utrudnia porównywalność wyników różnych badań, a także na niezbyt jasnym rozgraniczaniu przyczyn umieszczanych $\mathrm{w}$ ankietach, co $\mathrm{z}$ kolei utrudnia respondentom odpowiedzi. Jeszcze innym mankamentem jest to, że inhibitory aktywności turystycznej - czasami bardzo istotne - są pomijane. Jako przykład posłużyć może tzw. habitus, czyli w miarę regularne zachowania, które ograniczają człowieka w zakresie dokonywanych przez niego wyborów (KŁOSKOWSKA 1990, s. 9). Dotychczas nie podejmowano odrębnych badań, które dotyczyłyby wpływu tego zja- 
wiska na uprawianie turystyki. Tymczasem wydaje się, że habitus może być bardzo istotnym inhibitorem aktywności turystycznej. Dotyczy to ludzi, którzy nie korzystają z bogatej oferty turystycznej czyniąc tak nie ze względu na brak środków finansowych czy brak czasu, ale z powodu bariery, jaka stwarza im ich własny habitus związany z poziomem wiedzy, kompetencji czy stylem życia, ale także z własną cielesnością, nieznajomością języków obcych itd. Habitus dostarcza jednostce określony stały zestaw możliwych wyborów powodujący, że staje się ona przewidywalna, a wręcz "zniewolona” społecznie poprzez konieczność podejmowania decyzji i działań mieszczących się w ramach własnego habitusu.

Wiele wskazuje na to, że badania atrybucji dotyczących przyczyn braku aktywności turystycznej są jednym z najbardziej zaniedbanych obszarów studiów nad aktywnością turystyczną. Obraz tej aktywności, uzyskiwany w wyniku standardowych i cyklicznie prowadzonych, ale jednak cechujących się często poważnymi mankamentami metodologicznymi badań koncentrujących się na wielkości i charakterze uczestnictwa, warto uzupełnić szczegółowymi analizami na temat przyczyn nieuczestniczenia w turystyce w ogóle, jak i w poszczególnych jej formach.

Już wiele lat temu K. PRZECŁAWSKI (1997, s. 40) twierdził, że „w przyszłości konieczne stanie się poznanie nie tylko motywów skłaniających do wyjazdów turystycznych, ale także motywów wstrzymujących, blokujących decyzję wyjazdu turystycznego". Oprócz dużego znaczenia dla działalności marketingowej, poznanie tych motywów wydaje się niezwykle istotne dla polityki turystycznej państwa, gdyż nie tylko ułatwić może identyfikacje trwałych barier ograniczających aktywność turystyczną poszczególnych osób, ale pozwala też na przewidywanie pewnych ogólnych trendów.

\section{Bibliografia}

ALEJZIAK W., 2006, Projekt 211/ITiR/2006 „Funkcjonalna typologia uwarunkowań aktywności turystycznej oraz próba stworzenia modelu wyjaśniającego jej fenomen”, realizowany w Instytucie Turystyki i Rekreacji AWF w Krakowie.

ALEJZIAK W., 2007, Inhibitory aktywności turystycznej. Teoretyczne i metodologiczne aspekty studiów nad ograniczeniami i barierami uczestnictwa w wyjazdach wypoczynkowych, „Folia Turistica”, 17.

ALEJZIAK W., 2009, Determinanty i zróżnicowanie społeczne aktywności turystycznej, „Studia i Monografie", 56, AWF w Krakowie, Kraków.

AlEJZIAK W., 2011, Tourist Activity: International and Domestic Diversification and the Problem of Social Exclusion, "Turyzm/Tourism”, 21, 1/2.

ALEJZIAK W., 2013, Tourist activity inhibitors, „International Journal of Culture, Tourism and Hospitality Research", 7(1). 
CBOS, 2005, Wyjazdy Polaków na wypoczynek w latach 1992-2005. Komunikat z badań, Centrum Badania Opinii Społecznej, Warszawa, http://www.cbos.pl/SPISKOM.POL/2005/K_185_05.PDF.

Eurobarometer, 1979, Holiday Travel October-November 1997 (Principal Investigator Anna Melich, European Commission). Zentralarchiv für Empirische Sozialforschung an der Universität zu Köln, http:/ / www.za.uni-koeln.de/data/en/eurobarometer/codebooks/s2959cdb.pdf.

Eurobarometer, 2011, Survey on the attitudes of Europeans towards Tourism, Analytical Report, Flash Eurobarometer - 328, February.

Eurobarometer, 2013, Attitudes of Europeans towards Tourism, Report, Flash Eurobarometer - 370, March.

Eurobarometer, 2015, Prefereces of Europeans towards Tourism, Report, Flash Eurobarometer - 414, March.

Filozofia a nauka. Zarys encyklopedyczny, 1987, Polska Akademia Nauk, Ossolineum, Wrocław-Warszawa-Kraków-Gdańsk-Łódź.

FÖrsterling F., 2005, Atrybucje. Podstawowe teorie, badania i zastosowanie, Gdańskie Wyd. Psychologiczne, Gdańsk.

GoEldner CH.R., Ritchie B.J.R., 2006, Tourism. Principles, Practices, Philosophies, 10 ${ }^{\text {th }}$ edition, John Viley \& Sons, New Jersey.

HAUKELAND J.V., 1990, Socio-cultural impacts of tourism in Scandinavia, „Tourism Management”, 5.

HEMPEL C.G., OPPENHEIM P., 1948, Studies in the Logic of Explanation, ", Philosophy of Science”, 15.

HEMPEL C.G., 1968, Podstawy nauk przyrodniczych (tł. B. Stanosz), Wyd. Naukowo-Techniczne, Warszawa.

JANKOWSKI K.W., 2006, Turystyka młodzieży szkolnej i akademickiej, [w:] J. Kosiewicz i K. Obodyński (red.), Turystyka i rekreacja. Wymiary teoretyczne i praktyczne, Wyd. Uniwersytetu Rzeszowskiego, Rzeszów.

KARPIŃSKI J., 1985, Przyczynowość w badaniach socjologicznych, PWN, Warszawa.

Kelly H., MiCHElA J., 1980, Attribution theory and Research, „Annual Review of Psychology”, 31.

KŁosKowsKA A., 1990, Teoria socjologiczna Pierre'a. Bourdieu, [w:] P. Bourdieu, J.C. Passeron (red.), Reprodukcje. Elementy teorii systemu nauczania, PWN, Warszawa.

KOTARBIŃSKI T., 1965, Traktat o dobrej robocie, wyd. 3. poprawione i rozszerzone, Zakład Narodowy im. Ossolińskich, PAN, Wrocław-Warszawa-Kraków.

ŁACIAK J., 2005, Uczestnictwo Polaków w wyjazdach turystycznych w 2005 roku, Instytut Turystyki, Warszawa.

ŁAZAREK R., 1999, Ekonomika turystyki, Wyższa Szkoła Ekonomiczna, Warszawa.

MORAWSKI J., 2000, Podejście przyczynowo-skutkowe. Rysowanie problemów, [w:] Wybrane problemy metodologii badań na potrzeby sportu, PTNKF, Warszawa.

MOTYCKA A., 1984, Relatywistyczna wizja nauki. Wprowadzenie. Filozoficzny spór o naukę, Ossolineum, Wrocław.

NAGEL E., 1985, Struktura Nauki. Zagadnienia logiki wyjaśnień naukowych, PWN, Warszawa.

NEKRAŠAS E., 1992, Wiedza prawdopodobna, PWN, Warszawa.

NiKITIN E., 1975, Wyjaśnianie jako funkcja nauki, PWN, Warszawa.

PRZECŁAWSKI K., 1997, Człowiek a turystyka. Zarys socjologii turystyki, Albis, Kraków.

SCHENK J., 2008, Analiza przyczynowa w systemach rekursywnych. Podejścia i podstawowe metody, WSIZ, Rzeszów.

Turystyka i wypoczynek w gospodarstwach domowych, 2005, Główny Urząd Statystyczny, Warszawa.

WASZCZYK M., SZCZERBICKI E., 2003, Metodologiczne aspekty opisowego modelowania w naukach ekonomicznych, "Zeszyty Naukowe Politechniki Gdańskiej - Filozofia”, 7, http://www.waszczyk. pl/publikacje/Metodologiczne.doc; 7.07.2006.

WTO, 1977, Factors influencing travel demand and leading to the redistribution of tourist movements. Doc. PG/I/2.2.2, WTO.

http://hal.psych.uw.edu.pl/2005zalaczniki/spolecna2005_6.pdf. 